The Agriculturists 18(1): 81-93 (2020) ISSN 2304-7321 (Online), ISSN 1729-5211 (Print)

A Scientific Journal of Krishi Foundation

Indexed Journal

DOI: https://doi.org/10.3329/agric.v18i1.49461

\title{
Adoption of Spices Cultivation Technology by the Growers in Shibganj Upazila under Bogura District of Bangladesh
}

\author{
M. S. I. Afrad ${ }^{1}$, M. R. Akter ${ }^{1}$, M. E. Haque ${ }^{1}$ and M. Zakaria ${ }^{2}$ \\ ${ }^{1}$ Department of Agricultural Extension and Rural Development; and ${ }^{2}$ Department of Horticulture, \\ Bangandhu Sheikh Mujibur Rahman Agricultural University, Gazipur, Bangladesh \\ *Corresponding author and Email: afrad69@gmail.com
}

Received: 16 April 2020

Accepted: 25 June 2020

\begin{abstract}
Traditionally, spices are important components used for preparation of everyday menu, especially for Bangladeshi. In this connection, Spices Research Center under Bangladesh Agricultural Research Institute (BARI) has been releasing new spices varieties but there is dearth of research on the adoption of these newly released spices varieties. Therefore, the present study aimed at to examine the extent of adoption of spices cultivation technology by the growers in Shibganj upazila under Bogura district. Data were collected from 90 household heads selected following proportionate random using a structured interview schedule. Major cultivating spices varieties which are noticed in the study area are BARI piaz1, BARI ada2, BARI holud5. Under the three major spices variety, 43.3 percent area was covered by small scale spices cultivation, 42.2 percent by medium scale and 14.5 percent was covered by large scale area of spices cultivation. Findings revealed that huge majority $(80.0 \%)$ of the respondents had medium adoption of BARI piaz1 whereas almost all $(93.3 \%)$ of them had medium adoption of BARI ada2. On the other hand, more than half $(53.3 \%)$ of the respondents had low adoption of BARI holud5 whereas 40.0 percent of them had medium and 6.7 percent had high adoption of the same. Vital perceived benefits that attracted the respondents in spices cultivation were higher price, yield and quality of the technologies than those of previous. BARI holud5 was found more profitable (BCR 1.7) than BARI piazl (BCR 1.3) and BARI ada2 (BCR 1.3). Respondent farmers' education, farm size, innovativeness, extension contact, knowledge on spices cultivation and annual family income showed significant and positive relationship with their adoption of spices technology.
\end{abstract}

Keywords: Spices, adoption, technology, cultivation

\section{Introduction}

Spices are a broad term used to describe herbal by-products that add flavor and aesthetic, aromatic and therapeutic treatments to food, drink and other items (Kumar et al., 2011). Spices may be either bark, buds, flowers, fruits, leaves, rhizomes, roots, seeds, stigmas and styles or the entire plant tops (Takeda et al., 2008).
Spices are those plants, the products of which are made use as food adjuncts to add aroma and flavor. Spices have some medicinal value such as turmeric is useful for reducing blood sugar, garlic is helpful for preserving memory and removing heart disease and ginger is well known for digestive property. Spices and condiments play quite an important role in the national economies of several spice-producing, importing 
and exporting countries of the world. Presently, 109 kinds of spices are cultivated in the world but in Bangladesh only 27 are used and produced only17. On the basis of area, yield, demand and availability, spices are divided into three categories viz. major, minor and exotic. Major spices are regularly used in daily diet at large amount such as chili, onion, garlic, turmeric, and ginger (Islam et al., 2011). Socioeconomically wise, spices provide means of earning living to many who operate on any of the activities within its value chain. In fact, studies by CAST (1984) and, Elias and Hossain (1984) among others show that spices are more profitable compared with other competing crops.

In Bangladesh, the area under the spices cultivation is 0.4 million hectares with annual production of 2.5 million metric tons and the annual demand of spices seeds are 3.0 million metric tons. Spices cover almost 2.6 percent of total cropped area in Bangladesh (BBS, 2018). Recently, the production rate of major spices like onion, garlic, chili, turmeric, and ginger are $0.174,3.82,0.130,0.140$ and 0.077 million metric tons, respectively (BBS, 2018). Nowadays, spices are valuable trade commodities in the world. They are expensive but widely used. Average per metric ton price of onion garlic, chili, ginger, and turmeric in US dollar are 320.0, 1305.0, 230.6, 876.4 and 3245.0, respectively (BBS, 2018).

The average area and production of spices are increasing in Bangladesh. However, it is reported that shrinkage of land resources is a limited scope to increase production of spices (Noor et al., 2008) but between the early 1970s and 2010s, spices production has increases by five times in Bangladesh (Deb, 2016). Therefore, a proper statistic of production and consumption is not available. The gap between demand and supply is also increasing. It is true that a good quantity of spices is being imported every year to meet the huge demand of people of the country at the cost of foreign currency. The imported cost of onion is $19300 \mathrm{Tk} / \mathrm{MT}$, garlic is 163980 $\mathrm{Tk} / \mathrm{MT}$ and ginger is $64460 \mathrm{Tk} / \mathrm{MT}$ (BBS, 2018).
The area under ginger, turmeric and onion increased by $1.6 \%, 1.5 \%$ and $0.6 \%$, respectively since independence. On the other hand, area of minor spices and Rabi chill decreased by $12.3 \%$ and $0.95 \%$, respectively. The insignificant growth rates of other spices indicate that their areas remained more or less same. The area of all spices is found to have declined by $0.33 \%$ per annum in Bangladesh (BBS, 2018). Production of all spices except turmeric, ginger and coriander shows negative growth rate in the postindependence period. Production of turmeric increased by $3.6 \%$ and ginger by $1.05 \%$ (BBS, 2018).

A number of research organizations are involved in research to improve the production and quality of spices. For the last two decades, BARI developed and released 18 (major-12, minor-6) disease resistance improved variety of spices. On the other hand, 81 technology on production, soil and water management; disease and insect management and post-harvest management have also been developed. BARI, BARC, DAE and NGOs have strengthened their works to extend these technologies. However, in Bangladesh, the national demand of spices consumption is much higher than the production of the same (Islam et al., 2011). Considering the importance of spices in Bangladesh, the Ministry of Agriculture established Spices Research Centre (SRC) under Bangladesh Agriculture Research Institute (BARI) in Shibganj upazila under Bogura district in 1996. So far 33 high-yielding varieties of 14 spices crops were invented along with 150 production technology.

It is well-known that success of any technology depends on its dissemination among the potential users which ultimately is measured by the level of adoption of the same. But there is dearth of research about the adoption status of these technologies by the growers. In view of the foregoing discussion, the researchers undertook this study entitled "adoption of spices cultivation technology by the growers in Shibganj upazila under Bogura district" to: (i) describe the socioeconomic characteristics of the spices growers in 
the study area; (ii) determine the extent of adoption of spices cultivation technology by the growers; (iii) investigate the perceived benefit of adoption of spices cultivation technology; (iv) compare the profitability of the selected spices; and (v) find out the relationships between socioeconomic characteristics of the growers and their extent of adoption of selected spices cultivation technology.

\section{Methodology}

The descriptive and diagnostic research design was used in the present study. The study was conducted in Shibganj upazila under Bogura district. Three unions viz. Shibganj, Mokamtala, and Bihar of the upazila were purposively selected because of intensive cultivation of spices. Total number of the spices cultivators in the three unions were 270 which constituted the population of the study. Among the listed 270 spices growers, 90 of them including 30 respondents for each spices technology were selected as sample following proportionate random sampling technique because of variation of number of sample population in the selected villages (Table 1).

In order to collect relevant information from the respondents, an interview schedule was carefully designed keeping the objectives of the study in view. The schedule contained both open and closed form questions which was pretested for its modification. Data were collected by the researchers during October to December 2018. The personal characteristics of the study were the selected characteristics of the respondents which included: age, education, family size, farm size, farming experience, training experience, annual income, knowledge on spices cultivation technology, organizational participation, contact with the sources of information and area under spices cultivation. On the other hand, adoption of selected spices cultivation technology was the focus variable of the study.

Age of the respondents were measured in actual year whereas education in schooling years and categorized following Rahman (2008) and training experience following Wadud (2010). Family size was measured in numbers of total member and farm size in hectare following Islam (2008) and BBS (2018), respectively. Annual family income was calculated in Tk., innovativeness in observed score, farming experience in years, extension contact in observed score and these were categorized following observed mean and standard deviation. Adoption quotient (AQ) of each spices cultivation technology was estimated following the formulae given by Kashem (2004) which considered both time and space dimensions simultaneously.

$\mathrm{AQ}=\frac{T 1}{T a} \times \frac{\mathrm{Tz}}{T a} \times \frac{A 1}{A 2} \times 100$

Where,

$\mathrm{AQ}=$ Adoption Quotient

$\mathrm{T}_{1}=$ Year since the selected spices cultivation technology was introduced in the study area

$T_{2}=$ Year since the user became aware of the selected spices cultivation technology

$\mathrm{T}_{3}=$ Year since the selected spices cultivation technology was adopted by the user

$\mathrm{A}_{1}=$ Potential area (ha.) under the selected spices cultivation technology during the surveyed year

$\mathrm{A}_{2}=$ Actual area (ha.) under the selected spices cultivation technology during the surveyed year

Three spices technologies viz. BARI piaz1, BARI holud5 and BARI ada2 were considered for this study. The adoption of these technologies was considered in percent which could range from 0 '-100 percent where ' 0 ' would indicate 'no adoption' and '100' percent indicate 'full adoption'. Perceived benefit index (PBI) of the selected spices was computed by obtaining their opinions on the five selected benefit statements in a five-point Likert-type scale. The continuums of the scale were "strongly agree', 'agree', 'no opinion', 'disagree' and 'strongly disagree' and the corresponding scores for these responses were ' 5 ', ' 4 ', ' ' 3 ', ' 2 ' and ' 1 '. Thus, total scores 
for each statement could range from ' 90 ' to '450'. Rank order of the statements were computed based on PBI score. Coefficients of correlation were employed to find out the relationships between the selected socioeconomic characteristics of the respondents and their adoption of spices cultivation technology against the null hypothesis of "there is no significant relationship between selected characteristics of the growers and their adoption of spices cultivation technology".

\section{Results and Discussion}

This section has been described into the following sub-sections as per objectives of the study.

\subsection{Selected socio-economic characteristics of the respondents}

Results shown in Table 2 demonstrate the majority $(67.8 \%)$ of the respondents were middle aged followed by young aged (18.9\%) and old aged $(13.3 \%)$. It is very important to have the mass involvement of the middle-aged farmers because they are responsible, energetic and stable in decision making. Highest portion $(61.1 \%)$ of the respondents had primary level education followed by 32.3 percent secondary level of education and 3.3 percent higher secondary level education compared to 3.3 percent illiterate. It is promising that there is very high rate $(96.7 \%)$ of literacy in the study area. Literate people are considerate, logical and economic in their lives. Major proportion $(60.0 \%)$ of them had small family size while
38.9 percent had medium family size and only 1.1 percent had large family size. Traditional joint family is transforming to modern nucleus family due to increasing literacy level among the farmers, therefore, greater portion of the family might be found in this category. More than half of $(51.1 \%)$ of them possessed medium farm size while 47.8 percent and 1.1 percent possessed small and large farm size, respectively. Farm size is an important determinant of agricultural production but due to increasing population, farm holding is fragmented in an alarming rate, therefore, greater portion of the farm holdings were found small in size. About half $(47.8 \%)$ of the respondents had low income while 40.0 percent had medium and 12.2 percent showed high income. This might be due to the reason that majority of respondents possessed small size farm and limited involvement in other sources of income.

Vital majority $(73.3 \%)$ of the respondents had medium extension contact while 14.5 percent had high extension contact and 12.2 percent had low extension contact. This might be due to their high literacy level which capable them to be involved with the contact with local extension agents to fulfill their thirst for agricultural knowledge. More than one-third of the respondents $(36.7 \%)$ had poor and medium training experience whereas 17.7 percent did not have any training at all and only 18.9 percent had high training experience. This might be due to poor arrangement of extension department to take them under training facility.

Table 1. Distribution of sample population and sample in the study area

\begin{tabular}{lccccccc}
\hline \multirow{2}{*}{ Villages } & \multicolumn{2}{c}{ Narandi } & \multicolumn{2}{c}{ Patuabhanga } & \multicolumn{2}{c}{ Hossendi } & Total \\
\cline { 2 - 6 } Spices & $\begin{array}{c}\text { Sample } \\
\text { population }\end{array}$ & Sample & $\begin{array}{c}\text { Sample } \\
\text { population }\end{array}$ & Sample & $\begin{array}{c}\text { Sample } \\
\text { population }\end{array}$ & Sample & sample \\
\hline Turmeric & 30 & 10 & 27 & 9 & 33 & 11 & 30 \\
Onion & 45 & 15 & 21 & 7 & 24 & 8 & 30 \\
Ginger & 30 & 10 & 23 & 8 & 37 & 12 & 30 \\
\hline Total sample & 105 & & 71 & & 94 & & 90 \\
population & & & & & & & 270 \\
\hline
\end{tabular}


Table 2. Selected characteristics of the respondents

\begin{tabular}{|c|c|c|c|c|c|c|c|}
\hline \multirow{2}{*}{$\begin{array}{c}\text { Variables } \\
\text { (Unit of } \\
\text { measurement) }\end{array}$} & \multicolumn{2}{|c|}{ Score range } & \multirow[b]{2}{*}{ Categories } & \multicolumn{2}{|c|}{ Respondents } & \multirow[b]{2}{*}{ Mean } & \multirow[b]{2}{*}{ SD } \\
\hline & Possible & Observed & & No. & $\%$ & & \\
\hline \multirow{3}{*}{ Age (Years) } & \multirow{3}{*}{ Unknown } & 28 & Young (22 to 35$)$ & 17 & 18.9 & \multirow{3}{*}{42.09} & \multirow{3}{*}{ - } \\
\hline & & to & Middle (36 to 50 ) & 61 & 67.8 & & \\
\hline & & 56 & Old (51 and above) & 12 & 13.3 & & \\
\hline \multirow{4}{*}{$\begin{array}{l}\text { Education } \\
\text { (Schooling } \\
\text { years) }\end{array}$} & \multirow{4}{*}{ Unknown } & \multirow{4}{*}{$0-12$} & Illiterate $(0)$ & 3 & 3.3 & \multirow{4}{*}{5.32} & \multirow{4}{*}{3.06} \\
\hline & & & Primary (1 to 5$)$ & 55 & 61.1 & & \\
\hline & & & Secondary (6 to 10$)$ & 29 & 32.3 & & \\
\hline & & & Higher secondary (above 10) & 3 & 3.3 & & \\
\hline \multirow{3}{*}{$\begin{array}{l}\text { Family size } \\
\text { (Number) }\end{array}$} & \multirow{3}{*}{ Unknown } & \multirow{3}{*}{$2-8$} & Small $(<5)$ & 54 & 60.0 & \multirow{3}{*}{4.32} & \multirow{3}{*}{1.29} \\
\hline & & & Medium (5-7) & 35 & 38.9 & & \\
\hline & & & Large (above 7) & 1 & 1.1 & & \\
\hline \multirow{3}{*}{$\begin{array}{l}\text { Farm size } \\
\text { (ha) }\end{array}$} & \multirow{3}{*}{ Unknown } & 0.53 & Small (0.02 to 1.01$)$ & 43 & 47.8 & \multirow{3}{*}{1.03} & \multirow{3}{*}{0.43} \\
\hline & & to & Medium (above 1.01to 3.03) & 46 & 51.1 & & \\
\hline & & 4.008 & Large (above 3.03) & 1 & 1.1 & & \\
\hline \multirow{3}{*}{$\begin{array}{l}\text { Annual } \\
\text { income (Tk.) }\end{array}$} & \multirow{3}{*}{ Unknown } & 80000 & Low (up to110000) & 43 & 47.8 & & \\
\hline & & to & Medium (110001 to 240000$)$ & 36 & 40 & 148978 & - \\
\hline & & 350000 & High (above 240000) & 11 & 12.2 & & \\
\hline Extension & & & Low (1 to 5$)$ & 11 & 12.2 & & \\
\hline contact & $0-12$ & $5-11$ & Medium (6 to 10$)$ & 66 & 73.3 & 8.42 & 1.61 \\
\hline (Score) & & & High (above 10) & 13 & 14.5 & & \\
\hline & & & No $(0)$ & 7 & 7.7 & & \\
\hline Training & Jnknown & $0-8$ & Poor $(1-3)$ & 33 & 36.7 & & \\
\hline experience & Unknown & $0-8$ & Medium (4-5) & 33 & 36.7 & 3.58 & - \\
\hline & & & High (above 5) & 17 & 18.9 & & \\
\hline & & & Low (1) & 20 & 22.2 & & \\
\hline mess & & & Medium (2) & 36 & 40.0 & & \\
\hline ness & $1-4$ & $1-4$ & High (3) & 22 & 24.5 & 2.29 & - \\
\hline & & & Very high (4) & 12 & 13.3 & & \\
\hline Farming & & & Low (1to 10) & 6 & 6.7 & & \\
\hline experience & Unknown & $10-32$ & Medium (11 to 20$)$ & 36 & 40.0 & 21.10 & 7.24 \\
\hline (Years) & & & High (above 20) & 48 & 53.3 & & \\
\hline Knowledge on & & & Low (up to 10) & 7 & 7.7 & & \\
\hline modern spices & $0-26$ & $8-24$ & Medium (11 to 20$)$ & 59 & 65.6 & 18.13 & 3.55 \\
\hline $\begin{array}{l}\text { cultivation } \\
\text { (Score) }\end{array}$ & & & High (above 20) & 24 & 26.7 & & \\
\hline
\end{tabular}

The highest proportion $(40.0 \%)$ of the respondents had medium innovativeness and 24.5 percent had high innovativeness, while 22.2 percent had low innovativeness and 13.3 percent had extremely high innovativeness. The high literacy status of the respondents might be influenced them to be innovative. Majority $(65.6 \%)$ of the farmers had medium knowledge on spices cultivation technology compared to 26.7 percent having high knowledge and only 7.7 percent had low knowledge about spices cultivation in the study area. Spices cultivation in 
the study area is conventional, therefore, they might follow their elderly persons to gather knowledge on spices cultivation.

\subsection{Adoption of spices cultivation technology}

Farmers' adoption of spices technology has been considered as the major concern of this study. Different aspects of this issue have been described in the subsequent sub-sections.

\subsubsection{Area under spices cultivation}

The mean and standard deviation of spices cultivation area were estimated 0.41 ha and 0.13 ha, respectively. Based on innovativeness scores, the respondents were classified into three categories. Information presented in Table 3 indicate that the majority $(43.3 \%)$ of the respondents had small cultivation area while the more or less same portion of the $(42.2 \%)$ had medium and 14.4 percent had large spices cultivation area. Therefore, more than four-fifth $(85.5 \%)$ of the respondent belonged to small to medium spices cultivation area.

These findings clearly indicate that most of the respondent had small to medium scale spices cultivation area. This might be due to their possession of small land holdings obtained from their ancestors. The amount of individual farmer's possession of cultivable land has been decreasing through fragmented distribution among the increasing successors from generation to generation.

\subsubsection{Duration of practicing spices cultivation} Based on the age of practicing spices, respondents were classified into three categories (Table 4). The mean and standard deviation of spices practicing were 17.58 years and 6.76 years, respectively.

Table 3. Distribution of the respondents based on their extent of spices cultivation area

\begin{tabular}{lcccc}
\hline \multicolumn{1}{c}{ Categories } & \multicolumn{2}{c}{ Respondents } & \multirow{2}{*}{ Mean } & \multirow{2}{*}{ SD } \\
\cline { 2 - 3 } & Number & Percent & & \\
\hline Small scale spices cultivation area (0.10 to 0.30 ha) & 39 & 43.3 & & \\
Medium scale spices cultivation area (0.31 to 0.60 ha) & 38 & 42.2 & \multirow{2}{*}{0.41} & \multirow{2}{*}{0.13} \\
Large scale spices cultivation area (above 0.60 ha) & 13 & 14.5 & & \\
\hline Total & 90 & 100.0 & & \\
\hline
\end{tabular}

Table 4. Distribution of the respondents based on their duration of practicing spices cultivation

\begin{tabular}{lcccc}
\hline \multicolumn{1}{c}{ Categories } & \multicolumn{2}{c}{ Respondents } & \multirow{2}{*}{ Mean } & \multirow{2}{*}{ SD } \\
\cline { 2 - 3 } & Number & Percent & & \\
\hline Short durational practice (1 to 10 years) & 25 & 27.8 & & \\
Medium durational practice (11 to 20 years) & 36 & 40.0 & \multirow{2}{*}{17.58} & \multirow{2}{*}{6.76} \\
Long durational practice (above 20 years) & 29 & 32.2 & & \\
\hline Total & 90 & 100.0 & \\
\hline
\end{tabular}

Table 5. Distribution of the respondents according to adoption of BARI piaz1

\begin{tabular}{lcccc}
\hline \multicolumn{1}{c}{ Categories } & \multicolumn{2}{c}{ Respondents } & \multirow{2}{*}{ Mean } & \multirow{2}{*}{ SD } \\
\cline { 2 - 3 } & Number & Percent & & \\
\hline Low adoption of BARI piaz1 (up to 33) & 4 & 13.3 & \multirow{2}{*}{43.8} & \multirow{2}{*}{12.7} \\
Medium adoption of BARI piaz1 (above 33 to 66) & 24 & 80.0 & \multirow{2}{*}{4.0} \\
High adoption of BARI piaz1 (above 66) & 2 & 6.7 & & \\
\hline Total & 30 & 100.0 & \\
\hline
\end{tabular}


Results presented in Table 4 indicate that the majority $(40.0 \%)$ of the respondents had medium durational practice of spices cultivation while 32.2 percent had long, and 27.8 percent had short durational practice of spices cultivation. Therefore, it is clearly indicated that almost three-fourth $(72.2 \%)$ of the respondent farmers had medium to long durational practice of spices cultivation. This might be due to high income from spices cultivation, tradition of area and familiar cultivation technique.

\subsubsection{Extent of adoption of BARI piaz1 cultivation technology}

The possible quotient for adoption of BARI piaz1 by the respondents could be from ' 0 ' to ' 100 ', while the observed range was 16.7 to 80.0. The mean adoption quotient was 43.8 and the standard deviation was 12.7. Based on observed range of extent of adoption, the respondents were classified into three categories as presented in Table 4. Information displayed in Table 5 reveal that majority $(80.0 \%)$ of the respondents had medium adoption of BARI piaz1 followed by low adoption (13.3\%) and only small portions $(6.7 \%)$ were having high adoption.

Findings clearly indicate that most of the farmers had medium adoption of BARI piaz1 cultivation in the study area. The reasons behind this result might be high production, availability of farming materials, and short duration of cultivation. But, Naik (2012) in a study pointed out that 79.6 percent of the farmers had low medium adoption of recommended cultivation practices of onion. Jadav and Munshi (2004) also reported that more than one-half $(56.7 \%)$ of the onion grower had medium level adoption about recommended onion production technology.

\subsubsection{Extent of adoption of BARI ada2 cultivation technology}

The possible adoption quotient of BARI ada2 could range from ' 0 ' to ' 100 ', while the observed range was 3.3 to 93.4 percent. The mean adoption quotient (was 42.4 percent and the standard deviation was 9.6. Based on observed range of extent of adoption, the respondents were classified into three categories as presented in Table 6 .

Information displayed in Table 6 reveal that majority (93.4\%) of the respondents had medium adoption of BARI ada2 followed by only 3.3 percent having low adoption high adoption. The finding clearly indicate that majority of the farmers had medium adoption of BARI ada2 cultivation in the study area. The reasons behind this might be high market price, better quality, non-complexity of cultivation and higher yield. Kharjana et al. (2017) showed that majority of the ginger growers $(72.5 \%)$ had medium level of adoption.

\subsubsection{Extent of adoption of BARI holud5 cultivation technology}

The possible adoption quotient of BARI holud5 could range from ' 0 ' to ' 100 ', while the observed range was 6.7 to 53.3 percent. The mean adoption quotient was 33.6 percent and the standard deviation was 17.2. Based on observed range of extent of adoption, the respondents were classified into three categories as presented in Table 7.

Table 6. Distribution of the respondents according to adoption of BARI ada2

\begin{tabular}{lcccc}
\hline \multicolumn{1}{c}{ Categories } & \multicolumn{2}{c}{ Respondents } & \multirow{2}{*}{ Mean } & \multirow{2}{*}{ SD } \\
\cline { 2 - 3 } & Number & Percent & & \\
\hline Low adoption of BARI ada2 (up to 33) & 1 & 3.3 & \multirow{2}{*}{9.6} \\
Medium adoption of BARI ada2 (above 33 to 66) & 28 & 93.4 & \multirow{2}{*}{42.4} & \\
High adoption of BARI ada2 (above 66) & 1 & 3.3 & & \\
\hline Total & 30 & 100.0 & \\
\hline
\end{tabular}


Table 7. Distribution of the respondents according to adoption of BARI holud5

\begin{tabular}{lcccc}
\hline \multicolumn{1}{c}{ Categories } & \multicolumn{2}{c}{ Respondents } & \multirow{2}{*}{ Mean } & \multirow{2}{*}{ SD } \\
\cline { 2 - 3 } & Number & Percent & & \\
\hline Low adoption of BARI holud5 (up to 33) & 16 & 53.3 & & \\
Medium adoption of BARI holud5 (above 33 to 66) & 12 & 40.0 & \multirow{2}{*}{33.6} & \multirow{2}{*}{17.2} \\
High adoption of BARI holud5 (above 66) & 2 & 6.7 & & \\
\hline Total & 30 & 100.0 & & \\
\hline
\end{tabular}

Table 8. Comparative percent area coverage of selected spices varieties

\begin{tabular}{ccccc}
\hline $\begin{array}{c}\text { Name of spices } \\
\text { variety }\end{array}$ & $\begin{array}{c}\text { Mean cultivated area (ha) } \\
\text { under each variety (a) }\end{array}$ & $\begin{array}{c}\text { Mean potential area } \\
\text { (ha) for cultivation (b) }\end{array}$ & $\begin{array}{c}\text { Extent of adoption } \\
\text { (a/b X 100) }\end{array}$ & Rank \\
\hline BARI piaz1 & 13.1 & 28.9 & 45.3 & 1 st \\
BARI ada2 & 12.9 & 30.9 & 41.7 & 2nd \\
BARI holud5 & 11.1 & 32.5 & 34.2 & 3rd \\
\hline
\end{tabular}

Information displayed in Table 6 reveal that majority $(53.3 \%)$ of the respondents had lower adoption of BARI holud5 followed by medium adoption $(40.0 \%)$ and only small portions $(6.7 \%)$ were having high adoption. Findings clearly indicate that the respondent farmers had low to medium adoption of BARI holud5 cultivation in the study area. The reasons behind this result might be complexity of cultivation and long duration of cultivation. Rao (2016) in a study revealed that majority of the farmers had medium level of adoption $(62.50 \%)$

\subsubsection{Comparative area coverage of different spices varieties}

Farmers in the study area were cultivating different spices varieties. Among the cultivars, three were major cultivated spices varieties. These were BARI piaz1, BARI ada2, and BARI holud5. A comparative percent area coverage of the three spices varieties were computed based on total average area covered as presented in Table 8.

Findings displayed in in Table 8 show that among the total spices cultivated area, BARI piaz1 covered the highest $(45.3 \%)$ area and ranked first position whereas BARI ada 2 covered 41.7 percent and BARI holud5 covered 34.2 percent ranking in $2^{\text {nd }}$ and $3^{\text {rd }}$ positions, respectively. The reason behind this result might be due to the reasons that inputs required for onion cultivation is more available and cheaper, cultivation technique is easier, yield per unit area is higher, storing is comparatively suitable, marketing facility is higher than those of BARI ada2 and BARI holud5.

\subsubsection{Perceived benefit of adoption of spices cultivation technology}

Results on respondents' perception of benefits accrued by cultivating spices in a fivecontinuum scale have been presented in Table 9.

As shown in Table 8 the first benefit of selected spices cultivation is the high market price. As the quality of spices is comparatively better and the price becomes higher than the other crops. 'Higher yield than other old variety' is another important perceived benefit of spices cultivation. The farmers might not to go to distant market to avail the spices seeds. The cultivation procedure of spices is almost similar to that of other crops. So, the farmers perceived more benefit regarding this statement. Studies (Elias and Hossain, 1984) found that spices are more profitable than that of their others competitive crops. Rahman (1993) also shown that net returns of turmeric, ginger and onion production are higher than Rabi vegetables production. 


\subsubsection{Comparative profitability of different spices cultivation}

Before initiating production of any crops, farmers are eager to know the ultimate benefit of this cultivation. Therefore, yield of BARI piaz1,
BARI ada2 and BARI holud5 along with total production cost, total return and net return were calculated for understanding the comparative profitability of these three spices variety. In this connection, BCR was computed considering total production cost and net return (Table 10).

Table 9. Perceived benefit of selected spices cultivation by the respondents

\begin{tabular}{|c|c|c|c|c|c|c|c|c|c|c|c|}
\hline \multirow{3}{*}{ Statement } & \multicolumn{10}{|c|}{ Extent of benefit perceived $(n=90)$} & \multirow{3}{*}{ PBI Rank } \\
\hline & \multicolumn{2}{|c|}{$* \mathrm{SA}(5)$} & \multicolumn{2}{|c|}{$\mathrm{A}(4)$} & \multicolumn{2}{|c|}{$\mathrm{NO}(3)$} & \multicolumn{2}{|c|}{$\mathrm{D}(2)$} & \multicolumn{2}{|c|}{ SD (1) } & \\
\hline & No. & $\%$ & No. & $\%$ & No. & $\%$ & No. & $\%$ & No. & $\%$ & \\
\hline High & 30 & 33.3 & 45 & 50.0 & 15 & 16.7 & 0 & 0.0 & 0 & 0.0 & 375 1st \\
\hline Better quality & 25 & 27.8 & 38 & 42.2 & 20 & 22.2 & 4 & 4.5 & 3 & 3.33 & $3483 \mathrm{rd}$ \\
\hline $\begin{array}{l}\text { Higher yield than } \\
\text { other old varieties }\end{array}$ & 30 & 33.3 & 40 & 44.5 & 12 & 13.3 & 7 & 7.8 & 1 & 1.11 & 361 \\
\hline $\begin{array}{l}\text { Non-complexity of } \\
\text { cultivation procedure }\end{array}$ & 0 & 0 & 10 & 11.1 & 16 & 17.8 & 64 & 71.1 & 0 & 0 & 21 \\
\hline Short durable variety & 15 & 16.7 & 25 & 27.8 & 15 & 16.7 & 30 & 33.3 & 5 & 5.56 & 285 4th \\
\hline
\end{tabular}

$* \mathrm{SA}=$ strongly agree, $\mathrm{A}=$ Agree, $\mathrm{NO}=$ No opinion, $\mathrm{D}=$ Disagree, $\mathrm{SD}=$ Strongly disagree

Table 10. Per hectare comparative profitability of different spices cultivation

\begin{tabular}{lccc}
\hline \multicolumn{1}{c}{ Item } & BARI piaz1 & BARI ada2 & BARI holud5 \\
\hline Yield (ton) & 16.0 & 17.5 & 18.7 \\
Total return (Tk.) & 331524.5 & 1028767.5 & 460192.1 \\
Total production cost (Tk.) & 143962.1 & 447854.3 & 168912.2 \\
Net return (Tk.) & 187562.4 & 580913.2 & 291279.9 \\
\hline BCR & 1.3 & 1.3 & 1.7 \\
\hline
\end{tabular}

Table 11. Relationship between of the selected characteristics of the respondents and their adoption of spices technology

\begin{tabular}{lcc}
\hline Selected characteristics & Focus variable & Coefficient of correlation (r) df (89) \\
\hline Age & -0.08 \\
Education & $0.23^{*}$ \\
Family size & -0.02 \\
Farm size & $0.22^{*}$ \\
Annual income & $0.26^{*}$ \\
Extension contact & Adoption of spices & $0.28^{*}$ \\
Training experience & cultivation technology & 0.14 \\
Innovativeness & & $0.24^{*}$ \\
Farming experience & & -0.19 \\
Knowledge on spices & & $0.26^{*}$ \\
cultivation technology & & \\
\hline
\end{tabular}

\footnotetext{
**Significant at 0.01 level of probability *Significant at 0.05 level of probability
} 
Results furnished in Table 9 reveal that among the three cultivated varieties, highest BCR (1.7) was found in BARI holud5. The reason behind higher BCR of BARI holud5 might be higher market price and lower production cost compared with other varieties. These findings reveal that BARI holud5 cultivation is more profitable than those of BARI piazland BARI ada2. Islam et al. (2011) reported 1.79 and 2.99 $\mathrm{BCR}$ for ginger and turmeric, respectively whereas BCR of onion was 2.13 (BBS, 2017). Huda et al. (2008) also reported that ginger appeared to be highly profitable spice crops having net return Tk. 2,82,011 per hectare followed by turmeric (Tk. 65,423 per hectare) and onion (Tk. 38,281 per hectare), accordingly.

\subsection{Relationship between the selected socio-} economic characteristics of the respondents and their adoption of spices cultivation technology

Correlation coefficient ' $r$ ' was calculated to find out the relationship between adoption of spices cultivation technology and selected socioeconomic characteristics of the respondents. The summary of the correlation analysis has been shown in Table 11.

\subsubsection{Education and adoption}

The correlation co-efficient between education of the respondents and their adoption of spices cultivation technology was found positive and significant at $5.0 \%$ level of probability $(\mathrm{r}=$ $0.23^{*}$ ) i.e. null hypothesis could not be accepted indicating that education of the farmers has significant positive relationship with their adoption of spices technology. Although spices cultivation requires special technical knowledge compare to other HYV of cereals, pulses, oil seeds and vegetables. However, during period of data collection, it was observed that farmers who were cultivating HYVs and Hybrid of cereals, pulses, oil seeds and vegetables were tended to migrate towards spices cultivation. Therefore, educational attainment of the respondents could influence their adoption behavior regarding spices cultivation. Riddell and Song (2012) and
Strauss et al. (1991) in their studies reported similar findings.

\subsubsection{Farm size and adoption}

The correlation co-efficient between farm size of the respondents and their adoption of spices technology was found positive and significant at $5.0 \%$ level of probability $(\mathrm{r}=0.22 *)$ which led to reject the null hypothesis indicating that farm size of the farmers has significant positive relationship with their adoption of spices technology. Innovation always involves some sorts of risks. Spices cultivation on the area not exception to this. Sometimes new technology used to fail in coping with new areas hence; there is a risk of failure. The farmers having large farm size can take this risk as trial basis and if they fail, they can compensate through other varieties. On the other hand, small farmers have no scope of taking risk for which they have to wait for a while in adopting new technology. Another fact is that the farmers couldn't always produce the quality seeds of modern spices varieties and depend on the seeds to be supplied from other sources. When the supply of seeds is limited, the farmers hardly continue its cultivation. It is obviously a risky situation especially for the small farmers. However, the medium and large farmers could take risk easily because of their diversified income source which compensate the losses. It is assumed that, the farmers having more farms land likely to adopt quickly spices in their cultivation practice. The similar findings were also observed for adoption of cotton (Rahman, 1995), potato (Sarker, 1997; Hasan, 2003) and mung bean (Islam, 2008).

\subsubsection{Annual family income and adoption}

The correlation co-efficient between annual income of the respondents and their adoption of spices cultivation technology was found positive and significant at $5.0 \%$ level of probability $(\mathrm{r}=$ $0.26^{*}$ ) which led to reject the null hypothesis indicating that annual family income has significant relationship with the adoption of spices technology. It may be concluded that annual family income of the farmers had a 
positively significant relationship with their adoption spices cultivation technology. Cultivation of spices requires risk bearing ability as because there is a risk of crop failure due to pest and disease infestation. Therefore, the respondents having more annual family income could able to take the risk to a considerable extent. Thus, with the increase of annual family income of the farmers, their adoption of spices cultivation tended to be increased. Hussen (2001) found that the annual family income of the cane growers had a positive significant relationship with their adoption sugarcane varieties. Khan (1993), Aurangozeb (2002) found the similar results in their respective studies.

\subsubsection{Extension contact and adoption}

The correlation co-efficient between extension contact of the respondents and their adoption of spices cultivation technology was found significant at $1.0 \%$ level of probability $(\mathrm{r}=$ $0.28 * *)$ which led to reject the null hypothesis indicating that contact with information sources have significant relationship with adoption of spices cultivation technology. Using a greater number of information sources means accumulating more information, empowering with higher level of knowledge and Technology. Similar results were observed by Strauss et al. (1991) in their studies.

\subsubsection{Innovativeness and adoption}

Computed values of the coefficient of correlation between of respondents and their adoption of spices cultivation technology were found positive and significant $(\mathrm{r}=0.24 *)$ with 98 degrees of freedom at $5.0 \%$ level of probability which led to reject the null hypothesis. The researcher hence concluded that the innovativeness of the farmers had a positive significant relationship with the adoption of spices cultivation technology. Higher innovativeness inspires farmers to adopt new technology and help them to overcome various problems. For this reason, innovative small farmers face less problems in adopting spices cultivation technology. Similar findings were reported by Hossain (2003).

\subsubsection{Knowledge on spices cultivation and adoption}

The correlation co-efficient between knowledge of the respondents and their adoption of spices cultivation technology was found positive and significant at $5.0 \%$ level of probability $(\mathrm{r}=$ $0.26^{*}$ ) which led to reject the null hypothesis indicating that knowledge on spices cultivation technology have significant relationship with the adoption of spices technology. Knowledge of the farmers on spices cultivation technology could inspire them to adopt spices cultivation technology. Besides the above-mentioned characteristics, age, family size, farming experience and training experience being not significant at 0.05 level of probability, the concerned null hypothesis could not be rejected and hence, it is concluded that none of these four characteristics had any significant relationship with the adoption of spices cultivation technology. Sarker (2016) showed similar results in his study on knowledge, adoption and constraint analysis of chili cultivation technology in Char area of Bangladesh.

\section{Conclusions}

Farmers in the study area demonstrated poor personal characteristics with small farm, low level education and annual income and poor training experience. Greater portion of them had medium adoption of BARI ada2 followed by BARI piaz1 and BARI holud5. High market price, higher yield and better quality than other existing other varieties of the selected spices influenced them for adoption. BARI holud5 showed highest profitability as compared to BARI piaz1 and BARI ada2. Education, farm size, innovativeness, extension contact, knowledge on spices cultivation and annual family income of the farmers showed significant positive relationship with their adoption of spices technologies. Increased adoption of spices technology is important for increasing the 
yield of spices. But a considerable proportion of the farmers had low spices technology adoption. It is, therefore, recommended that an effective step may be taken by the Department of Agricultural Extension (DAE) in dissemination of spices technology in the study area. Most of the farmers possessed medium and small farm size, may be given more attention to their farming operation as they generally work on their farm. Hence, the extension workers may utilize the small and medium farmers in their extension activities to introduce spices technology on a significant scale.

\section{References}

Aurangozeb MK. 2002. Adoption of integrated homestead farming technologies by the rural women in RDRS. MS Thesis, Agricultural Extension Education, Bangladesh Agricultural University, Mymensingh.

BBS. 2017. Yearbook of Agricultural Statistics in Bangladesh, Bangladesh Bureau of Statistics, Ministry of Planning, Government of the People's Republic of Bangladesh, Dhaka.

BBS. 2018. Yearbook of Agricultural Statistics in Bangladesh, Bangladesh Bureau of Statistics, Ministry of Planning, Government of the People's Republic of Bangladesh, Dhaka.

CAST (Canadian Agricultural Sector Team). 1984. Production and marketing of spices in Bangladesh: A Background Report, Dhaka.

Deb UK. 2016. Agriculture and food security. In: Riaz, A and Rahman, M.S. (Eds.), Routledge Handbook of Contemporary Bangladesh, (1 ${ }^{\text {st }}$ ed., pp.144-158), Routledge Publishing, Tayler and Fancies Group, London, and New York, DOI: https://doi.org/10.4324/9781315651019

Elias SM, Hossain MI. 1984. Chili cultivation in Bangladesh. agro-economic survey and constraints to it production at farm level, Gazipur, Bangladesh. Bangladesh
Agricultural Research Institute (BARI), Gazipur, Bangladesh.

Hasan MM. 2003. Adoption of recommended potato cultivation practices by the farmers in some selected area of Rajshahi district. MS Thesis, Agricultural Extension Education, Bangladesh Agricultural University, Mymensingh.

Hossain MM. 2003. Farmers' knowledge and adoption of modern boro rice cultivation practices. MS Thesis, Agricultural Extension Education, Bangladesh Agricultural University. Mymensingh.

Huda FA, Islam1 MS, Biswas H, Islam MS. 2008. Impact assessment study on selected spice crops under Action Plan in Bangladesh. Progressive Agriculture, 19(2): 229-241.

Hussen MA. 2001. Farmers' knowledge and adoption of modern sugarcane cultivation practices. MS Thesis, Department of agricultural Extension Education, Bangladesh Agricultural University, Mymensingh.

Islam A. 2008. Farmers' knowledge system and dissemination of mungbean cultivation in the south-western region of Bangladesh. $M S$ Thesis, Agricultural Extension and Rural Development, Bangabandhu Sheikh Mujibur Rahman Agricultural University. Gazipur.

Islam MR. 2008. Adoption of integrated plant nutrient system by the small farmers towards sustainable crop production. $M S$ Thesis, Agricultural Extension Education, Bangladesh Agricultural University. Mymensingh.

Islam MS, Rahman KM, Hasan MK. 2011. Profitability and resource use efficiency of producing major spices in Bangladesh. Bangladesh Journal of Agricultural Economics, 34: 1-2.

Jadav NB, Munshi MA. 2004. Adoption of recommended onion production technology. Gujrat Journal of Extension Education, 15:44-46. 
Kashem MA. 2004. Fundamentals of extension education. Bangladesh Agricultural University, Mymensingh. P.64-67

Khan MAH. 1993. Adoption of insecticides and related issues in the village of Pachar union, Madhupur district. MS Thesis, Agricultural Extension Education, Bangladesh Agricultural University, Mymensingh.

Kharjana NV, Bordoloi N, Sharma, S. 2017. A study on the extent of adoption of improved ginger cultivation practices by the farmers in Ri-Bhoi district of Meghalaya. International Journal of Agricultural Science and Research, 7(4):383-390.

Kumar A, Kumar A, Kaushal V, Patil S, Payal C, Kumar A. 2011. Antibacterial potential of some natural food preservations against staphylococcus aureus isolated from various food samples of Himachal pradesh (India), World Journal of Science and Technology, 1(10), 48-53.

Naik VR. 2012. A study on knowledge and adoption of recommended cultivation practices of onion by farmers. MS Thesis, Department of Agricultural Extension Education, College of Agriculture, Dharwad University of Agricultural Sciences, India.

Noor S., Khan MS, Shil NC, Talukder MR. 2008. Integrated nutrient management for sustainable yield of major spice crops in Bangladesh. Bangladesh Journal of Agricultural Environment, 4, 95-113.

Rahman M. 1995. Constraints faced by the farmers in cotton cultivation. MSc Thesis, Agricultural Extension Education, Bangladesh Agricultural University, Mymensingh.

Rahman MM. 1993. An economic study of resource use efficiency, women labor employment and income generation potentials of farmers practicing homesteadagro-forestry in Bangladesh, Report submitted to Winrock International, Dhaka.

Rahman MS. 2008. Farmers' response towards the cultivation of BRRI dhan33 to mitigate
Monga. MS Thesis, Agricultural Extension and Rural Development, Bangabandhu Sheikh Mujibur Rahman Agricultural University. Gazipur.

Rao NS. 2016. A study on knowledge and adoption of turmeric farmers in Guntur district of Andhra pradesh. B.Sc. (Ag.) Thesis, Department of Agricultural Extension, Acharya N.G. Ranga Agricultural University, Andhra Pradesh, India.

Riddell WC, Song X. 2012. The role of education in technology use and adoption: evidence from the Canadian workplace and employee survey, Discussion Paper No. 6377 February 2012.

Sarker DC. 1997. Correlates of selected characteristics of potato growers with their adoption of improved potato cultivation practices in five village of Comilla district. MS Thesis, Agricultural Extension Education, Bangladesh Agricultural University, Mymensingh.

Sarker MNI. 2016. Knowledge, adoption and constraint analysis of chili cultivation technology in Char area of Bangladesh. International Journal of Ecology and Development Research, 1(1):16-18.

Strauss J, Barbosa M, Teixeira S, Thomas D, Junior RG. 1991. Role of education and extension in the adoption of technology: a study of upland rice and soybean farmers in Central-West Brazil. Agricultural Economics, 5(4), 341-359. DOI: https://doi.org/10.1016/01695150(91)90027-I

Takeda J, De Silva S, Muthuraman P, Rahman SM, Kawet L. 2008. Spices in Sri Lanka, India and Bangladesh with special reference to the usages and consumptions. Bull. Faculty of Agriculture, Saga University, 93:1-25.

Wadud F. 2010. Impact of commercial flower cultivation on the livelihood of its growers in Bangladesh. PhD Dissertation, Agricultural Extension and Rural Development, Bangabandhu Sheikh Mujibur Rahman Agricultural University, Gazipur. 